\title{
HUBUNGAN KUALITAS PELAYANAN PERSALINAN DENGAN KEPUASAN IBU BERSALIN DI RUMAH SAKIT IBU DAN ANAK (RSIA) SRIRATU MEDAN TAHUN 2019
}

\author{
Desi Lustiyani Putri Ndruru ${ }^{1(\mathrm{~K})}$, Herbert Wau ${ }^{2}$ Putranto Manalu ${ }^{3}$ \\ ${ }^{1}$ Bidang Administrasi Kebijakan Kesehatan, Kesehatan Masyarakat, Universitas Prima Indonesia, \\ Medan, Indonesia \\ ${ }^{2}$ Bidang Epidemiologi, Kesehatan Masyarakat, Universitas Prima Indonesia, Medan, Indonesia \\ ${ }^{3}$ Bidang Administrasi Kebijakan Kesehatan, Kesehatan Masyarakat, Universitas Prima Indonesia, \\ Medan, Indonesia \\ ${ }^{1}$ Email Penulis Korespondensi ${ }^{(\mathrm{K})}$ : desilustiyaniputri@gmail.com
}

\begin{abstract}
Health development to increase awareness, willingness, and the ability of everyone to be able to behave in a healthy life to achieve the specified health status. Quality health services are efficient health services, in contrast health services that are lacking or not quality will make the organization's services very wasteful and exfoliate expensive costs. Based on the results of an initial survey that has been carried out, data on maternal and maternal visits at the Sri Ratu Medan Mother and Child Hospital (RSIA) in the last 3 years showed a declining number in 2015 of 681 births, 2016 in 573 births, in 2017 a total of 2017505 maternity mothers. This is because there has been a lot of competition between hospitals regarding the quality of childbirth services which is sufficient to provide satisfaction for maternity mothers. Research Objectives: To Know the Relationship Between Service Quality and Maternal Satisfaction at Sri Ratu's Mother and Child Hospital in Medan in 2019. Research Methods: The research method used is quantitative research with cross sectional research. The population in this study were maternity patients at RSIA Sri Ratu Medan with a total sample of 83 people. Analysis using chi square test with $\alpha<0.05$. Research Results: shows the $p$-value between Physical Evidence ( $p$-value 0.001), Reliability ( $p$-value 0,000), Responsiveness ( $p$-value 0.001), Guarantee ( $p$-value 0.115), Attention ( $p$-value 0.243) on maternal satisfaction at RSIA Sri Ratu Medan in 2019.Conclusion: There is a supportive relationship between physical evidence, compatibility, responsiveness to maternal satisfaction and there is no relationship between assurance and attention to maternal satisfaction at Sri Ratu Hospital in 2019
\end{abstract}

Keywords: Physical evidence, Reliability, Responsiveness, Guarantee, Maternal Mortality.

\section{ABSTRAK}

Pembangunan kesehatan adalah upaya untuk meningkatkan kesadaran, kemauan, serta kemampuan setiap orang untuk dapat berperilaku hidup sehat untuk mencapai derajat kesehatan yang setinggi-tingginya.Layanan kesehatan yang berkualitas adalah layanan kesehatan yang efisien, sebaliknya layanan kesehatan yang kurang atau tidak bermutu adalah akan membuat layanan organisasi menjadi sangat boros dan mengelurkan biaya yang mahal. Berdasarkan hasil survei awal yang telah dilakukan, data kunjungan ibu bersalin di Rumah Sakit Ibu dan Anak (RSIA) Sri Ratu Medan dalam 3 tahun terakhir menunjukan angka yang menurun pada tahun 2015 sebanyak 681 ibu bersalin, tahun 2016 sebanyak 573 ibu bersalin, tahun 2017 sebanyak 505 ibu bersalin. Hal ini dikarenakan sudah banyaknya persaingan antar rumah sakit mengenai kualitas pelayanan persalinan yang cukup memberikan kepuasan bagi ibu bersalin. Penelitian ini bertujuan untuk mengetahui hubungan kualitas pelayanan persalinan dengan kepuasan ibu bersalin di RSIA Sri Ratu Medan. Metode penelitian yang digunakan adalah penelitian kuantitatif dengan pendekatan cross sectional. Populasi dalam penelitian ini adalah pasien ibu bersalin di RSIA Sri Ratu Medan dengan jumlah sampel 83 orang. Analisis dengan menggunakan uji chi square dengan $\alpha<0,05$. Hasil penelitian 
menunjukan bahwa nilai $p$-value antara bukti fisik ( $p$-value 0,001$)$, kehandalan ( $p$-value 0,000$)$, daya tanggap ( $p$-value 0,001$)$, jaminan ( $p$-value 0,115$)$, perhatian $(p$-value 0,243$)$ terhadap kepuasan ibu bersalin di RSIA Sri Ratu Medan. Kesimpulan: Terdapat hubungan yang bermakna antara bukti fisik, kehandalan, daya tanggap terhadap kepuasan ibu bersalin dan tidak terdapat hubungan yang bermakna antara jaminan dan perhatian terhadap kepuasan Ibu Bersalin di RSIA Sri Ratu Medan.

Kata Kunci : Bukti fisik, Kehandalan, Daya Tanggap, Jaminan, PerhatianKepuasan Ibu Bersalin.

\section{PENDAHULUAN}

Pembangunan kesehatan adalah upaya peningkatan kesadaran, kemauan, serta kemampuan setiap orang untuk dapat berperilaku hidup sehat dalam rangka mencapai derajat kesehatan yang setinggi-tingginya. Seiring dengan meningkatnya kesadaran masyarakat untuk meningkatkan derajat kesehatan maka penyedia layanan jasa kesehatan dituntut untuk selalu memberikan pelayanan yang terbaik kepada pasien.

Derajat kesehatan masyarakat suatu negara dipengaruhi oleh keberadaan sarana kesehatan. Undang-Undang Nomor 36 Tahun 2009 tentang Kesehatan menyatakan bahwa fasilitas pelayanan kesehatan adalah suatu alat dan/atau tempat yang digunakan untuk menyelenggarakan upaya pelayanan kesehatan, baik promotif, preventif, kuratif, maupun rehabilitatif yang dilakukan oleh pemerintah, pemerintah daerah, dan/atau masyarakat. Sarana kesehatan yang diulas pada pada bagian ini terdiri dari fasilitas pelayanan kesehatan, sarana kefarmasian dan alat kesehatan, serta institusi pendidikan kesehatan milik pemerintah yang menghasilkan tenaga kesehatan. Fasilitas pelayanan kesehatan yang dibahas pada bagian ini terdiri dari Puskesmas dan rumah sakit.

Layanan kesehatan yang berkualitas adalah layanan kesehatan yang efisien, sebaliknya layanan kesehatan yang kurang atau tidak bermutu adalah akan membuat layanan organisasi menjadi sangat boros dan mengelurkan biaya yang mahal. Organisasi layanan kesehatan yang menghasilkan layanan yang bermutu akan selalu dihormati oleh masyarakat dan pasti akan dicari oleh pasien. Dengan demikian layanan kesehatan yang terjamin kualitas nya adalah layanan kesehatan yang kompetitif. Layanan kesehatan yang bermutu adalah layanan kesehatan yang berupaya memenuhi harapan pasien sehingga pasien akan selalu merasa berhutang budi serta sangat berterimakasih, sehingga pasien akan bercerita kemana-mana dan kepada setiap orang untuk menyebarluaskan segala hal yang baik tersebut sehingga pasien atau masyarakat akan berperan menjadi petugas hubungan masyarakat dari setiap organisasi layanan kesehatan yang baik mutunya.

Untuk mengatasi adanya perbedaan dimensi tentang masalah pelayanan kesehatan seharusnya pedoman yang di pakai adalah hakekat dasar dari di selenggaranya pelayanan kesehatan. Hakekat dasar tersebut adalah memenuhi kebutuhan dan tuntunan para pemakai jasa pelayanan kesehatan yang apabila berhasil di penuhi akan menimbulkan rasa puas terhadap pelayanan kesehatan yang diselenggarakan. Jadi, kualitas pelayanan kesehatan adalah menunjuk pada tingkat pelayanan kesehatan yang menunjukan rasa puas pada diri setiap pasien.Makin sempurna kepuasan tersebut, makin baik pula mutu pelayanan kesehatan.

Berdasarkan data Legatum Prosperity Index Luxembourg (2016), berada pada peringkat 1 dari 149 negara yang memiliki pelayanan kesehatan terbaik. Hal ini di karenakan pelayanan kesehatan di Luxembourg berkualitas sangat tinggi serta kebebasan biaya pelayanan kesehatan kepada masyarakat dan jaminan peningkatan harapan hidup. Sedangkan berdasarkan data Legatum Prosperity Index 2017, Indonesia berada pada peringkat 101 dari 149 Negara yang masih memiliki pelayanan kesehatan rendah. Ini di karenakan kualitas pelayanan kesehatan yang masih belum merata terutama daerah yang tertinggal serta kekurangan fasilitas kesehatan yang tersedia tidak memadai dan tidak lengkap (Legatum Institute, 2018).

Berdasarkan Profil Kesehatan Indonesia Tahun 2017, terdapat $83,67 \%$ ibu hamil yang menjalani persalinan dengan ditolong oleh tenaga kesehatan dan dilakukan di fasilitas pelayanan kesehatan di Indonesia. Sedangkan Profil Kesehatan Sumatera Utara tahun 2017 menunjukan 82,70 
$\%$ Ibu hamil menjalani persalinan dengan pertolongan tenaga kesehatan. Secara nasional, indikator tersebut telah memenuhi target Renstra yang sebesar 79\%. Namun demikian masih terdapat 17 provinsi (50\%) yang belum memenuhi target tersebut (Kementerian Kesehatan RI, 2018).

Laporan Riset Kesehatan Dasar 2010 menunjukan 70,4\% kelahiran pada periode 1 Januari 2010 saat sampai wawancara terjadi di fasilitas kesehatan dan polindes/poskesdes dengan presentasi tertinggi yaitu di rumah sakit, rumah bersalin, klinik, praktek dokter/praktek bidan sebesar 38,0\% dan terendah di poskesdes sebesar 3,7\%. Namun masih terdapat 29,6\% yang melahirkan di rumah/lainnya (Kementerian Kesehatan RI, 2011).

Hasil penelitian yang dilakukan oleh Nurpahmi dkk (2016) dengan judul Faktor Yang Berhubungan Dengan Kepuasan Ibu Hamil Terhadap Kualitas Pelayanan Antenatal Care di Puskesmas Keluarahan Cibubur Kecamatan Ciracas bulan Juni tahun 2015, menunjukan ada hubungan yang signifikan antara ketanggapan pelayanan persalinan dengan kepuasan Ibu Hamil. Hasil penelitian yang dilakukan oleh Sudian (2012) dengan judul penelitian Hubungan Kepuasan Pasien Terhadap Mutu Pelayanan Kesehatan di RS Cut Mutia Kabupaten Aceh Utara, menunjukan ada hubungan yang bermakna antara komunikasi dengan kepuasan pasien di rumah sakit, ada hubungan yang bermakna antara sikap petugas kesehatan dengan kepuasan pasien di rumah sakit dan ada hubungan bermakna antara empati dengan kepuasan pasien di rumah sakit.

Selanjutnya hasil penenlitian yang dilakukan oleh Kahar dkk. (2017) dengan judul penelitian Pengaruh Persepsi Mutu Pelayanan Kebidanan Terhadap Kepuasan Pasien Rawat Inap di RSUD Barru Sulawesi Selatan Tahun 2017, menunjukan ada pengaruh keandalan, ketanggapan, jaminan, empati dan bukti langsung dengan kepuasan pasien rawat inap di RSUD Barru 2017. Pada penelitian tersebut juga peneliti menekankan bahwa variabel kehandalan merupakan faktor yang paling berpengaruh terhadap Kepuasan pasien rawat inap di RSUD Barru tahun 2017.

Data kunjungan ibu bersalin di Rumah Sakit Ibu dan Anak (RSIA) Sri Ratu Medan dalam 3 tahun terakhir menunjukan angka yang menurun pada tahun 2015 sebanyak 681 ibu bersalin, tahun 2016 sebanyak 573 ibu bersalin, tahun 2017 sebanyak 505 ibu bersalin. Hal ini dikarenakan sudah banyaknya persaingan antar rumah sakit mengenai kualitas pelayanan persalinan yang cukup memberikan kepuasan bagi ibu bersalin.

Hasil survei dan wawancara terhadap 10 orang pasien ibu bersalin di RSIA Sri Ratu Medan pada bulan September 2018, 6 (enam) orang pasien ibu bersalin mengatakan kurang puas dengan pelayanan rumah sakit tersebut, hal ini dikarenakan kualitas pelayanan persalinan yang diberikan kurang optimal seperti sarana dan prasarana layanan persalinan, tingkat kehadiran dan ketanggapan petugas dalam melakukan tindakan yang sangat kurang, waktu tunggu dokter yang lama, tidak adanya kesiapan petugas di tempat pendaftaran, proses pendaftaran pasien atau ibu bersalin masih secara manual, pelayanan petugas yang kurang tanggap atau kurang cepat melayani, ketersediaan fasilitas seperti lift yang mulai tidak berfungsi normal, tempat tidur yang mulai rusak, dan keluhan selimut yang sangat tipis. Masih kurangnya kebersihan, baik di ruang rawat ibu bersalin maupun ruang persalinan yang masih terasa panas dan bau ruangan yang kurang sedap. 2 (dua)orang pasien ibu bersalin mengatakan puas dikarenakan keramahan petugas dalam melayani ibu bersalin sedangkan 2 (dua) orang mengatakan biasa-biasa saja karena masih banyak yang harus ditingkatkan sebagaimana citra maupun gambaran rumah sakit yang diharapkan oleh masyarakat dalam memberikan pelayanan yang mendukung bagi pasien.

Berbagai upaya yang dilakukan di dalam meningkatkan kualitas pelayanan persalinan, namun masih terdapat keluhan pasien terhadap pelayanan di RSIA Sri Ratu Medan. Tujuan penelitian ini adalah untuk mengetahui hubungan kualitas pelayanan persalinan dengan kepuasan ibu bersalin di Rumah Sakit Ibu dan Anak (RSIA) Sri Ratu Medan.

\section{METODE}

Jenis penelitian ini bersifat survei analitik dengan menggunakan desain studi cross-sectional yaitu mencari hubungan variable independen (bukti fisik (tangibles), kehandalan (reliabilty), ketanggapan (responsiveness), jaminan (assurance), dan perhatian (empaty)) dengan variabel 
dependen (kepuasan ibu bersalin) dalam waktu yang bersamaan. Populasi dalam penelitian ini adalah semua pasien ibu bersalin dengan jumlah kunjungan pasien ibu bersalin 1 tahun terakhir pada tahun 2017 di Rumah Sakit Ibu dan Anak Sri Ratu Medan sebanyak 505 ibu bersalin. Sampel penelitian dihitung dengan menggunakan rumus Solvin.

$$
\begin{gathered}
\mathrm{n}=\frac{N}{1+\left(N \cdot e^{2}\right)} \\
\mathrm{n}=\frac{505}{1+\left(505 \cdot 0,1^{2}\right)} \\
\mathrm{n}=83
\end{gathered}
$$

keterangan :

$\mathrm{n}=$ jumlah sampel

$\mathrm{N}=$ jumlah populasi

$d=$ standard error (ditetapkan 10\% dengan tingkat kepercayaan 90\%).

Berdasarkan perhitungan di atas jumlah sampel dalam penelitian ini adalah 83 orang pasien ibu bersalin di RSIA Sri Ratu Medan. Teknik pengambilan sampel yang digunakan adalah simple random sampling dengan ditentukan berdasarkan kriteria inklusi dan eksklusi.

Adapun kriteria yang diambil peneliti adalah:

1. Kriteria Inklusi dalam penelitian ini adalah:

a. Pasien ibu bersalin di RSIA Sri Ratu Medan

b. Pasien sehat jasmani dan rohani

c. Bersedia menjadi responden dalam penelitian

2. Kriteria Eksklusi dalam penelitian ini adalah subjek yang menolak untuk berpatisipasi.

Penelitian ini dilakukan pada bulan Juli 2019. Pengumpulan data dalam penelitian dilakukan dengan wawancara dengan menggunakan kuesioner. Uji statistik dengan menggunakan uji chi square $\left(\mathrm{X}^{2}\right)$ dengan tingkat kepercayaan 95\% menggunakan program SPSS versi 16.0.

\section{HASIL}

Distribusi Frekuensi Berdasarkan Umur, Pendidikan, Pekerjaan Pasien Ibu Bersalin di RSIA Sri Ratu Medan Tahun 2019.

Tabel 1

Distribusi Frekuensi Berdasarkan Umur, Pendidikan, Pekerjaan

Pasien Ibu Bersalin di RSIA Sri Ratu Medan Tahun 2019

\begin{tabular}{lll}
\hline Karakteristik & Jumlah & Persentase (\%) \\
\hline Umur & & \\
\hline $17-26$ Tahun & 29 & 34,9 \\
$27-36$ Tahun & 47 & 56,6 \\
$37-46$ Tahun & 7 & 8,4 \\
\hline Total & $\mathbf{8 3}$ & $\mathbf{1 0 0}$ \\
\hline Pendidikan & & \\
\hline SMP & 3 & 3,6 \\
SMA & 39 & 47,0 \\
Akademi & 14 & 16,9 \\
Sarjana & 27 & 32,5 \\
\hline Total & $\mathbf{8 3}$ & $\mathbf{1 0 0}$ \\
\hline Pekerjaan & & \\
\hline IRT & 44 & 53,0 \\
PNS & 12 & 14,5 \\
Pegawai Swasta & 8 & 9,6 \\
Wiraswasta & 19 & 22,9 \\
\hline Total & $\mathbf{8 3}$ & $\mathbf{1 0 0}$ \\
\hline
\end{tabular}


Berdasarkan tabel 1 diperoleh data kelompok umur responden yakni mayoritas responden kelompok umur 27 - 36 tahun sebanyak 47 responden (56,6\%) dan minoritas kelompok umur 37 46 tahun sebanyak 7 responden $(8,4 \%)$.

Berdasarkan distribusi frekuensi pendidikan responden, mayoritas pendidikan SMA sebanyak 39 responden $(47,0 \%)$ dan minoritas pendidikan SMP sebanyak 3 responden $(3,6 \%)$ dan distribusi frekuensi pekerjaan responden, mayoritas ibu rumah tangga (IRT) sebanyak 44 orang $(53,0 \%)$ dan minoritas pegawai swasta sebanyak 8 responden $(9,6 \%)$.

\section{Analisis Univariat}

Distribusi Frekuensi Responden Berdasarkan Pelayanan Bukti Fisik, Pelayanan Kehandalan, Pelayanan Daya Tanggap, Pelayanan Jaminan, Pelayanan perhatian Dengan Kepuasan Ibu Bersalin di RSIA Sri Ratu Medan Tahun 2019

Tabel 2

Distribusi Frekuensi Responden Berdasarkan Pelayanan Bukti Fisik,

Pelayanan Kehandalan, Pelayanan Daya Tanggap, Pelayanan Jaminan, Pelayanan perhatian Dengan Kepuasan Ibu Bersalin di RSIA Sri Ratu Medan Tahun 2019.

\begin{tabular}{lll}
\hline Variabel & Jumlah $(\mathbf{n})$ & Persentase (\%) \\
\hline Bukti Fisik & 42 & 50,6 \\
Baik & 41 & 49,4 \\
Tidak Baik & 46 & 55,4 \\
\hline Kehandalan & 44,6 \\
Baik & 37 & \\
Tidak Baik & & 49,4 \\
\hline Daya Tanggap & 41 & 50,6 \\
Baik & 42 & \\
Tidak Baik & & 47,0 \\
\hline Jaminan & 39 & 53,0 \\
Baik & 44 & \\
Tidak Baik & & 41,0 \\
\hline Perhatian & 34 & 59,0 \\
Baik & 49 & 41,0 \\
Tidak Baik & & 59,0 \\
\hline Kepuasan Pasien & 34 & \\
Puas & 49 & \\
Tidak Puas &
\end{tabular}

Berdasarkan tabel 2 di atas dapat dilihat bahwa mayoritas responden menyatakan bukti fisik baik sebanyak 42 orang $(50,6 \%)$, dan minoritas responden menyatakan bukti fisik pelayanan 41 orang $(49,4 \%)$. Berdasarkan kehandalan pelayanan, mayoritas responden menyatakan kehandalan pelayanan baik sebanyak 46 orang $(55,4 \%)$ dan minoritas responden menyatakan kehandalan pelayanan tidak baik sebanyak 37 orang $(44,6 \%)$. Berdasarkan daya tanggap pelayanan, mayoritas responden menyatakan daya tanggap pelayanan tidak baik sebanyak 42 orang $(50,6 \%)$ dan minoritas responden menyatakan daya tanggap baik sebanyak 41 orang $(49,4)$.

Pada dimensi jaminan pelayanan, mayoritas responden menyatakan jaminan pelayanan tidak baik sebanyak 44 orang $(53,0 \%)$ dan minoritas responden menyatakan jaminan pelayanan baik sebanyak 39 orang $(47,0 \%)$. Berdasarkan perhatian pelayanan, mayoritas responden menyatakan perhatian pelayanan tidak baik sebanyak 49 orang $(59,0 \%)$ dan minoritas responden menyatakan sebanyak 34 orang $(41,0 \%)$. Berdasarkan kepuasan pasien ibu bersalin, mayoritas responden 
menyatakan tidak puas sebanyak 49 orang $(59,0 \%)$ dan minoritas reponden menyatakan tidak puas sebanyak 34 orang $(41,0 \%)$.

\section{Analisis Bivariat}

Distribusi Frekuensi Responden Berdasarkan Pelayanan Bukti Fisik, Pelayanan Kehandalan, Pelayanan Daya Tanggap, Pelayanan Jaminan, Pelayanan perhatian Dengan Kepuasan Ibu Bersalin di RSIA Sri Ratu Medan Tahun 2019.

Tabel 3

Distribusi Frekuensi Responden Berdasarkan Pelayanan Bukti Fisik,

Pelayanan Kehandalan, Pelayanan Daya Tanggap, Pelayanan Jaminan, Pelayanan perhatian Dengan Kepuasan Ibu Bersalin di RSIA Sri Ratu Medan Tahun 2019.

\begin{tabular}{|c|c|c|c|c|c|c|c|}
\hline \multirow{3}{*}{ Variabel } & \multicolumn{4}{|c|}{ Kepuasan Pasien } & \multirow{3}{*}{$\mathbf{n}$} & \multirow{3}{*}{$\%$} & \multirow{3}{*}{ p Value } \\
\hline & \multicolumn{2}{|c|}{ Puas } & \multicolumn{2}{|c|}{ Tidak Puas } & & & \\
\hline & $\mathbf{N}$ & $\%$ & $\mathbf{n}$ & $\%$ & & & \\
\hline \multicolumn{8}{|l|}{ Bukti Fisik } \\
\hline Baik & 25 & 59,5 & 17 & 40,5 & 42 & 100 & \multirow{2}{*}{0,001} \\
\hline Tidak Baik & 9 & 22,0 & 32 & 78,0 & 41 & 100 & \\
\hline \multicolumn{8}{|l|}{ Kehandalan } \\
\hline Baik & 28 & 60,9 & 18 & 39,1 & 46 & 100 & \multirow{2}{*}{0,000} \\
\hline Tidak Baik & 6 & 16,2 & 31 & 83,8 & 37 & 100 & \\
\hline \multicolumn{8}{|l|}{ Daya Tanggap } \\
\hline Baik & 30 & 73,2 & 11 & 21,4 & 41 & 100 & \multirow{2}{*}{0,000} \\
\hline Tidak Baik & 4 & 9,5 & 38 & 90,5 & 42 & 100 & \\
\hline \multicolumn{8}{|l|}{ Jaminan } \\
\hline Baik & 20 & 51,3 & 19 & 48,7 & 39 & 100 & \multirow{2}{*}{0,115} \\
\hline Tidak Baik & 14 & 31,8 & 30 & 68,2 & 44 & 100 & \\
\hline \multicolumn{8}{|l|}{ Perilaku } \\
\hline Baik & 17 & 50,0 & 17 & 50,0 & 34 & 100 & \multirow{2}{*}{0,243} \\
\hline Tidak Baik & 17 & 34,7 & 32 & 65,3 & 49 & 100 & \\
\hline
\end{tabular}

Hasil analisis bivariat dengan menggunakan uji chi-square diperoleh nilai $p$-value $=0,001$ ( $p$ value $<0,05)$, artinya Ho ditolak dan Ha diterima, ini menunjukkan bahwa terdapat hubungan yang signifikan antara pelayanan bukti fisik dengan kepuasan ibu bersalin di RSIA Sri Ratu Medan. Hasil analisis bivariat dengan menggunakan uji chi-square diperoleh nilai $p$-value 0,000 ( $p$-value $<0,05)$, artinya Ho ditolak dan Ha diterima, ini menunjukkan bahwa ada hubungan yang signifikan antara pelayanan kehandalan dengan dengan dengan kepuasan ibu bersalin di RSIA Sri Ratu Medan. Hasil analisis bivariat dengan menggunakan uji chi-square diperoleh nilai $p$-value 0,000 ( $p$-value $<0,05)$, artinya Ho ditolak dan Ha diterima, ini menunjukkan bahwa ada hubungan yang signifikan antara pelayanan daya tanggap dengan kepuasan ibu bersalin di RSIA Sri Ratu Medan. Hasil analisis bivariat dengan menggunakan uji chi-square diperoleh nilai dengan $p$-value $=0,115$ ( $p$-value $>0,05$ ), artinya Ho diterima dan Ha ditolak, ini menunjukkan bahwa tidak ada hubungan yang signifikan antara pelayanan jaminan dengan kepuasan ibu bersalin di RSIA Sri Ratu Medan. Hasil analisis bivariat dengan menggunakan uji chi-square diperoleh nilai $p$-value $=0,243$ ( $p$-value $>0,05)$, artinya Ho diterima dan Ha ditolak, ini menunjukkan bahwa tidak ada hubungan yang signifikan antara pelayanan perhatian dengan kepuasan ibu bersalin di RSIA Sri Ratu Medan. 


\section{PEMBAHASAN}

\section{Hubungan Bukti Fisik Dengan Kepuasan Ibu Bersalin di RSIA Sri Ratu Medan Tahun 2019}

Hasil analisis bivariat dengan menggunakan uji chi-square diperoleh nilai $p$-value $=0,001$ ( $p$ value $<0,05)$, artinya Ho ditolak dan Ha diterima, ini menunjukkan bahwa ada hubungan yang signifikan antara pelayanan bukti fisik dengan kepuasan ibu bersalin di RSIA Sri Ratu Medan.

Hal ini sejalan dengan penelitian yang dilakukan oleh Haposanita dkk. (2014) di Puskesmas Kota Semarang dengan judul penelitian "Hubungan Antara Persepsi lbu Hamil Tentang Mutu Pelayanan Antenatal Dengan Kepuasan Ibu Hamil di Puskesmas Krobokan Kota Semarang" diperoleh hasil analisis bivariat dengan metode chi-square $=14,430$ pada tingkat signifikan $95 \%$ dan $p=0,000$. Karena nilai $p<0,05$ maka dapat dinyatakan bahwa terdapat hubungan bukti fisik terhadap kepuasan ibu hamil. Dalam penelitian yang dilakukan oleh Reinissa dan Indrawati (2017) dengan judul "Persepsi Ibu Nifas Tentang Pelayanan Postnatal Care dengan Kunjungan Ulang" menyatakan bahwa ada hubungan antara persepsi ibu nifas tentang bukti langsung pelayanan postnatal care dengan minat kunjungan ulang layanan postnatal care. Dalam penelitian tersebut juga peneliti menyatakan bahwa Semakin baik persepsi bukti langsung responden terhadap mutu pelayanan postnatal care, maka minat kunjungan ulang layanan postnatal care cenderung lebih banyak dan sebaliknya. Bukti langsung dalam penelitian ini dapat ditunjukkan dengan memiliki ruang tunggu yang mencukupi dan bersih, tersedia kamar mandi yang bersih, memiliki alat medis yang modern dan berfungsi dengan baik, ruangan periksa dalam keadaan bersih, rapi dan nyaman, tempat tidur periksa dalam keadaan bersih dan rapi, bahan habis pakai selalu diperbaharui, dan penampilan bidan selalu bersih dan rapi.

Menurut asumsi peneliti dari 42 responden, yang menjawab baik bukti fisik kualitas pelayanan yang diberikan, mayoritas responden merasa puas sebanyak 25 orang $(59,5 \%)$. Hal ini berarti responden merasa puas dengan kenyamanan dan kelengkapan fasilitas yang ada di RSIA Sri Ratu Medan. Dari 42 responden yang menjawab baik bukti fisik dalam kualitas pelayanan yang diberikan, minoritas responden menjawab tidak puas sebanyak 17 orang $(40,5 \%)$ artinya responden tidak puas akan kenyamanan dan kelengkapan fasilitas yang ada dikarenakan kondisi sarana dan prasarana yang ada di rumah sakit kurang memadai, kebersihan yang kurang, penerangan ruang persalinan, kebersihan serta ketenangan ruangan persalinan yang kurang (bising). Sedangkan 41 responden yang menjawab bukti fisik pelayananan persalinannya tidak baik, mayoritas responden menjawab tidak puas sebanyak 32 orang $(78,0 \%)$ dan minoritas responden menjawab puas sebanyak 9 orang (22,0\%). Hal ini dapat dirasakan dan dilihat secara langsung oleh responden dengan merasakan pelayanan dari fasilitas fisik dan sarana dan prasarana yang tersedia di RSIA Sri Ratu Medan. Dapat disimpulkan bahwa pelayanan bukti fisik yang baik dan memadai berhubungan dengan kepuasan ibu bersalin, semakin baik kualitas pelayanan bukti fisik maka tingkat kepuasan pasien semakin tinggi sebaliknya jika pelayanan bukti fisik masih rendah akan membuat minat dan kepuasan pasien juga semakin rendah.

Kepuasan adalah perasaan senang atau kecewa seseorang yang muncul setelah membandingkan antara persepsi/kesannya terhadap kinerja (atau hasil) suatu produk dan harapanharapannya (Asmuji, 2012). Kepuasan responden merupakan suatu promosi terbaik, jika pelanggan yang merasa puas terhadap pelayanan yang di berikan kepadanya dapat di ceritakan atau direferensikan kepada orang lain sesuai dengan apa yang telah diterimanya. Hal tersebut dapat menjadi pengaruh baik untuk mendapatkan kunjungan kembali.

Penelitian Nwaeze dkk (2013) menunjukkan bahwa wanita hamil yang menerima perawatan pada pada klinik antenatal care menyatakan bahwa layanan klinik baik serta merasa puas dengan pelayanan yang diberikan dan akan kembali pada kehamilan berikutnya serta merekomendasikan kepada teman-temannya. Pohan (2007) menyatakan bahwa mutu pelayanan kesehatan menunjukan pada tingkat kesempurnaan pelayanan kesehatan dalam menimbulkan rasa puas diri setiap pasien, makin sempurna kepuasan tersebut makin baik pula mutu pelayanan kesehatan. 


\section{Hubungan Kehandalan Dengan Kepuasan Ibu Bersalin di RSIA Sri Ratu Medan Tahun 2019}

Hasil analisis bivariat dengan menggunakan uji chi-square diperoleh nilai $p$-value 0,000 ( $p$ value $<0,05)$, artinya Ho ditolak dan Ha diterima, ini menunjukkan bahwa ada hubungan yang signifikan antara pelayanan kehandalan dengan dengan dengan kepuasan ibu bersalin di RSIA Sri Ratu Medan. Penelitian yang dilakukan oleh Nazariah dan Marianthi (2016) dengan judul penelitian "Tingkat kepuasan Ibu Post Partum RSUD Meuraxa Kota Banda Aceh" menunjukan hasil bahwa tingkat kepuasan Dimensi reliability pada ibu post partum berada dalam kategori tidak puas sebanyak 31 responden $(53,4 \%)$. Hal ini dapat dilihat dari hasil penelitian yang bahwa tingkat kepuasan ibu post partum dalam kategori tidak puas disebabkan pelayanan dalam memberikan asuhan keperawatan pada ibu post partum kurang. Pemeriksaan hanya sekedar saja dan tidak dilakukan secara menyeluruh dan apabila ibu post partum memerlukan bantuan maka perawat atau bidan tidak segera datang. Pada saat perawat atau bidan melaksanakan asuhan keperawatan masih banyak perawat tidak memberikan pelayanan dengan baik yaitu perawat masih banyak yang cemberut pada saat memberikan pelayanan. Pemeriksaan yang dilakukan pada ibu post partum hanya melihat keadaan fisik saja tidak memeriksaa keadaan mental ibu dan bayi.

Menurut asumsi peneliti dari 46 responden, yang menjawab baik pelayanan kehandalan mayoritas mengatakan puas sebanyak 28 orang $(60,9 \%)$ dan minoritas menjawab tidak puas sebanyak 18 orang $(39,1 \%)$. Dari 37 responden yang menjawab pelayanan kehandalan tidak baik, mayoritas responden menjawab tidak puas sebanyak 31 orang $(83,8 \%)$ dan minoritas responden menjawab puas sebanyak 6 orang $(16,2 \%)$. Ini menunjukan bahwa ada hubungan pelayanan kehandalan dengan kepuasan ibu bersalin yaitu masih kuranngnya kemampuan untuk menyediakan pelayanan yang terpercaya supaya dapat mengahasilkan kepuasan terhadap ibu bersalin diantaranya kurangya kemampuan petugas dalam menangani pada saat proses persalinan, pelayanan yang baik oleh petugas terhadap pasien, dan keberadaan dokter di rumah sakit di saat pasien sedang dalam keadaan gawat darurat.

Penelitian Ramez (2012) menunjukkan bahwa responden memiliki persepsi yang tinggi terhadap dimensi kehandalan sehingga berpengaruh dengan kualitas pelayanan. Dimensi pada kualitas pelayanan tersebut memiliki hubungan signifikan dengan kepuasan pasien dan niat perilaku pasien.

Hasil penelitian ini menguatkan pendapat Zahruli (2006) mengatakan bahwa kehandalan adalah kemampuan memberikan pelayanan yang sesuai secara akurat dan terpercaya, sikap simpatik dengan akurasi yang tinggi kepada para pasien. Keandalan diukur dengan tindakan pelayanan yang akurat oleh tenaga medis puskesmas, profesionalisme, dalam menangani keluhan pasien oleh para tenaga medis puskesmas, melayani dengan baik dan ramah saat melakukan pengobatan dan perawatan, memberikan pelayanan dengan tepat dan benar sesuai dengan prosedur yang ditetapkan dalam memberikan pelayanan selalu sesuai dengan jadwal yang telah ditetapkan.

\section{Hubungan Daya Tanggap DenganKepuasan Ibu Bersalin di di RSIA Sri Ratu Medan Tahun 2019}

Hasil analisis bivariat dengan menggunakan uji chi-square diperoleh nilai $p$-value 0,000 ( $p$ value $<0,05)$, artinya Ho ditolak dan Ha diterima, ini menunjukkan bahwa ada hubungan yang signifikan antara pelayanan daya tanggap dengan dengan dengan kepuasan ibu bersalin di RSIA Sri Ratu Medan.

Penelitian yang dilakukan oleh Nazariah dan Marianthi (2016) menunjukan hasil bahwa tingkat kepuasan pada dimensi responsivenes pada ibu post partum berada dalam kategori tidak puas sebanyak 33 responden (56,9\%). Peneliti menilai bahwa tidak puasnya ibu post partum disebabkan oleh tidak cepat dan tepat pemberian pelayanan keperawatan yang diberikan oleh perawat. Hasil observasi yang dilakukan pelayanan yang kurang cepat diberikan oleh pihak rumah sakit mulai dari loket, laboratorium, apotik dan sampai pelayanan medis yang harus menunggu dalam waktu yang sangat lama sehingga ibu post partum merasa tidak puas atas yang diberikan oleh pihak rumah sakit atau perawat. Pelayanan pada dimensi ini masih perlu ditingkatkan agar sesuai dengan harapan responden terutama dalam hal perhatian bidan ketika ibu bersalin merasa kesakitan 
dan pelayanan yang kurang serta harus menunggu dalam waktu lama saat membutuhkan pelayanan keperawatan.Pada dimensi responsiveness (cepat tanggap) perlu adanya peningkatan mutu pelayanan.

Menurut asumsi peneliti dari 41 responden yang menjawab baik pelayanan daya tanggap, mayoritas menjawab puas sebanyak 30 orang $(37,2 \%)$ dan minoritas menjawab tidak puas sebanyak 11 orang $(26,8 \%)$. Dari 42 responden yang menjawab tidak baik pelayanan daya tanggap, mayoritas menjawab tidak puas sebanyak 38 orang $(90,5 \%)$ dan minoritas menjawab puas sebanyak 4 orang $(9,5 \%)$. Dimana responden kurang puas terhadap pelayanan daya tanggap yang diberikan. Hal ini dapat dilihat dari jawaban responden yang menyatakan masih kurang nya kecepatan dan ketepatan penerimaan pasien, masih kurangnya penjelasan yang diberikan oleh petugas di lokasi penerimaan serta ketepatan dokter dalam menangani pasien masih kurang dikarenakan dokter tidak selalu berada di rumah sakit. Dapat disimpulkan bahwa daya tanggap juga menjadi hal yang perlu ditingkatkan dalam pelayanan persalinan yaitu kemampuan dan kesanggupan untuk membantu dan menyediakan pelayanan secara cepat dan tepat serta tanggap terhadap keinginan pasien.

Hasil penelitian ini menguatkan teori Tjiptono (2006) daya tanggap yaitu suatu kemampuan perusahaan untuk membantu dan memberikan pelayanan yang cepat dan tepat kepada pelanggan, dengan penyampaian informasi yang jelas. Parasuraman dkk. (1994) menyatakan penilaian yang mempengaruhi baiknya kualitas pelayanan pada dimensi responsiveness atau ketanggapan yaitu suatu kemauan untuk membantu dan memberikan pelayanan yang cepat dan tepat kepada pelanggan, dengan penyampaian informasi yang jelas. Prosedur pelayanan menjadi salah satu indikator penting dalam dimensi ini. Untuk dapat memberikan pelayanan secara cepat dan tepat tentu salah satu caranya adalah prosedur pelayanan yang jelas. Prosedur pelayanan harus tetap dimaksimalkan serta dikomunikasikan dengan baik agar masyarakat dapat memahami secara penuh prosedur pelayanan.

\section{Hubungan Jaminan Dengan Kepuasan Ibu Bersalin di di RSIA Sri Ratu Medan Tahun 2019}

Hasil analisis bivariat dengan menggunakan uji chi-square diperoleh nilai dengan $p$ value = 0,115 ( $p$ value> 0,05), artinya Ho diterima dan Ha ditolak, ini menunjukkan bahwa tidak ada hubungan yang signifikan antara pelayanan jaminan dengan kepuasan ibu bersalin di RSIA Sri Ratu Medan. Hal ini tidak sejalan dengan penelitian yang dilakukan oleh Haposanita dkk. (2014) di mana dinyatakan bahwa terdapat hubungan jaminan (assurance) terhadap kepuasan.

Menurut asumsi peneliti dari 39 responden, yang menjawab baik pelayanan jaminan mayoritas menjawab puas sebanyak 20 orang $(51,3 \%)$ dan minoritas menjawab tidak puas sebanyak 19 orang $(48,7 \%)$. Dari 44 responden yang menjawab tidak baik pelayanan jaminan, mayoritas menjawab tidak puas sebanyak 30 orang $(68,2 \%)$ dan mayoritas menjawab puas sebanyak 14 orang $(31,8 \%)$. Artinya responden beranggapan bahwa pengetahuan dan keramahan petugas dalam memberikan pelayanan yang baik serta kemampuan petugas dalam menanamkan kepercayaan dan kenyamanan dalam dirinya sehingga responden tak ada keragu-raguan dalam menerima pelayanan yang diberikan. Dari hasil uji chi-square yang diperoleh bahwa tidak terdapat hubungan jaminan dengan kepuasan ibu bersalin, dengan demikian apabila pelayanan jaminan semakin meningkat maka kepuasan tidak akan meningkat dan apabila pelayanan jaminan semakin menurun maka kepuasan tidak akan menurun.

\section{Hubungan Perhatian Dengan Kepuasan Ibu Bersalin di RSIA Sri Ratu Medan Tahun 2019}

Hasil analisis bivariat dengan menggunakan uji chi-square diperoleh nilai $p$-value $=0,243(p$ value $>0,05$ ), artinya Ho diterima dan Ha ditolak, ini menunjukkan bahwa tidak ada hubungan yang signifikan antara pelayanan perhatian dengan kepuasan ibu bersalin di RSIA Sri Ratu Medan.

$\mathrm{Hal}$ ini tidak sejalan dengan penelitian yang dilakukan oleh Nazariah dan Marianthi (2016) dengan hasil bahwa tingkat kepuasan Dimensi emphaty pada ibu post partum berada dalam kategori tidak puas sebanyak 32 responden (55,2\%). Peneliti menilai bahwa sikap empati yang diberikan oleh petugas kesehatan masih sangat kurang. Karena petugas kesehatan masih kurang berkomunikasi 
dengan teurapetik. Berdasarkan hasil hasil pengisian angket pasien mengatakan bahwa perawat dan bidan kurang memahami kebutuhan khusus pasien, hanya menjalankan seadaanya dan tidak dilakukan dengan sepenuh hati. Petugas kesehatan kurang merasa empati terhadap keadaan yang diderita atau yang dialami oleh seorang pasien dan masih banyak perawat atau bidan saat memberi pelayanan kehatan tdak ramah kepada pasien/cemberut sehingga ibu post partum merasa tidak puas. Sedangkan dalam peenlitian yang dilakukan oleh Putri dkk. (2015) menunjukkan bahwa empati bidan dalam memberikan pelayanan persalinan program Jampersal di BPM Yulia sudah memuaskan. Berdasarkan hasil wawancara dengan responden menunjukkan bahwa responden mengatakan hal-hal yang berkaitan dengan empati bidan dalam memberikan pelayanan persalinan program Jampersal di BPM Yulia di antaranya yaitu bidan memberikan perhatian kepada setiap pasiennya dengan baik, cara bidan memberikan perhatiannya kepada setiap pasien yaitu dengan mendengarkan keluhan pasien, diberikan nasehat, baik, sabar, tidak galak, bidan selalu bertanya kepada pasien terhadap keluhan pasien selama proses persalinan, bidan memberikan pelayanan kepada semua pasien tanpa memandang status. Tidak membeda-bedakan pasien yang ikut program Jampersal dengan pasien umum. Hasil wawancara dengan bidan dan kader secara keseluruhan mengatakan bahwa empati bidan dalam memberikan pelayanan persalinan program Jampersal di BPM Yulia sudah baik sehingga ibu bersalin merasa puas.

Menurut asumsi peneliti dari 34 responden, yang menjawab baik pelayanan perhatian, mayoritas responden menjawab puas sebanyak 17 orang $(50,0 \%)$ dan minoritas menjawab tidak puas sebanyak 17 orang (50,0\%). Dari 49 responden yang menjawab tidak baik pelayanan perhatian, mayoritas menjawab tidak puas sebanyak 32 orang $(65,3 \%)$ dan minoritas menjawab puas sebanyak 17 orang $(34,7 \%)$. Artinya proses pelayanan yang diberikan kepada pasien harus secara terbuka, keinginan pasien adalah dilayani dengan jujur. Dari hasil uji chi-square yang diperoleh bahwa tidak terdapat hubungan perhatian dengan kepuasan ibu bersalin. Dengan demikian dapat dinyatakan bahwa dimensi perhatian tidak mempengaruhi kepuasan ibu bersalin, apabila pelayanan perhatian meningkat maka tidak mempengaruhi peningkatan terhadap kepuasan pasien sebaliknya jika pelayanan perhatian semakin rendah maka tidak akan mempengaruhi kepuasan pasien.

\section{KESIMPULAN}

Berdasarkan hasil penelitian tentang Hubungan Kualitas Pelayanan Persalinan dengan Kepuasan Ibu Bersalin di Rumah Sakit Ibu dan Anak (RSIA) Sri Ratu Medan, maka diperoleh kesimpulan bahwa terdapat hubungan kualitas pelayanan persalinan berdasarkan bukti fisik (tangible), kehandalan (realibility), dan daya tanggap (responsiveness) dengan kepuasan ibu bersalin di RSIA Sri Ratu Medan. Sedangkan jaminan (assurance), dan perhatian (empaty) tidak memiliki hubungan dengan kepuasan ibu bersalin di RSIA Sri Ratu Medan.

\section{SARAN}

Di harapkan untuk meningkatkan kualitas pelayanan persalinan terhadap ibu bersalin yang meliputi sarana prasarana atau fasilitas yang ada di rumah sakit, serta lebih memperhatikan kemampuan dalam memberikan pelayanan yang baik terhadap pasien serta ketepatan dan kecepatan dalam menangani pasien ibu bersalin.

\section{DAFTAR PUSTAKA}

Asmuji, 2012. Manajemen Keperawatan: Konsep dan Aplikasi. Arruzz Media, Yogyakarta.

Haposanita, R., Jati, Sutopo, P., Suparwati, A., 2014. Hubungan Antara Persepsi Ibu Hamil Tentang Mutu Pelayanan Antenatal Dengan. J. Kesehat. Masy. 2, 157-162.

Kahar, A.W., Palu, B., Raodhah, S., 2017. Pengaruh Persepsi Mutu Pelayanan Kebidanan terhadap Kepuasan Pasien Rawat Inap di RSUD Barru Sulawesi Selatan Tahun 2017. Al-Sihah Public Heal. Sci. J. 9, 112-127.

Kementerian Kesehatan RI, 2018. Profil Kesehatan Indonesia Tahun 2017. Jakarta.

Kementerian Kesehatan RI, 2011. Riset Kesehatan Dasar 2010. Jakarta. 
Legatum Institute, 2018. The Legatum Prosperity Index 2017 [WWW Document]. URL https://www.prosperity.com/rankings (accessed 11.11.18).

Nazariah, Marianthi, D., 2016. Tingkat Kepuasan Ibu Post Partum Rumah Sakit Umum Daerah Meuraxa Kota Banda Aceh. Jurnail IIm. Mhs. Fak. Keperawatan 1, 1-7.

Nurpahmi, I., Emilia, 2016. Faktor-Faktor Yang Berhubungan Dengan Kepuasan Ibu Hamil Terhadap Kualitas Pelayanan Antenatal Care Di Puskesmas Kelurahan Cibubur Kecamatan Ciracas Bulan Juni Tahun 2015 8, 35-40.

Nwaeze, I.L., Enabor, O.O., Oluwasola, T.A.O., Aimakhu, C.O., 2013. Nigeria 2017 Ibadan. Ann. Ibadan Postgrad. Med. 11, 22-28.

Parasuraman, A., Zeithaml, V.A., Berry, L.L., 1994. Reassessment of Expectations as a Comparison Standard in Measuring Service Quality: Implications for Further Research. J. Mark. 58, 111. https://doi.org/10.2307/1252255

Pohan, I., 2007. Jaminan Mutu Layanan Kesehatan: Dasar-Dasar Pengertian dan Penerapan. EGC, Jakarta.

Putri, A., Herawati, S., Mustika, D.N., 2015. Gambaran Tingkat Kepuasan Ibu Bersalin Tentang Pelayanan Persalinan Program Jampersal Di BPM Yulia Kota Semarang. J. Kebidanan Univ. Muhammadiyah Semarang 2.

Ramez, W., 2012. Patients' perception of health care quality, satisfaction and behavioral intention: an empirical study in Bahrain. Int. J. Bus. Soc. Sci. 3, 131-141.

Reinissa, A., Indrawati, F., 2017. Persepsi Ibu Nifas tentang Pelayanan Postnatal Care dengan Kunjungan Ulang. Higeia J. Public Heal. 1, 109-119.

Sudian, T., 2012. Hubungan Kepuasan Pasien terhadap Mutu Pelayanan Kesehatan di Rumah Sakit Cut Mutia Kabupaten Aceh Utara. J. Kesehat. Masy. 1-10.

Tjiptono, F., 2006. Manjemen Jasa. Andi Publisher, Yogyakarta.

Zahruli, 2006. Pendekatan Mutu dan Kepuasan Dalam Pelayanan Kesehatan. UNHAS, Medan. 